\title{
A Critical Book Review of I've Been Meaning to Tell You: A Letter to My Daughter by David Chariandy
}

\author{
Reviewed by Sherine Douglas
}

\begin{abstract}
Sherine Douglas is a graduate student at the Ontario Institute for Studies in Education and a certified educator in Ontario, Canada. Her passion is teaching young people. Her research interests include race relations, educational policy, and law and ethics. As an educator in the public school system for the past ten years, Sherine has developed her teaching praxis and competencies to include a lens focused on system approaches in and around schools. Her leadership has taken her out of the classroom and into boardlevel positions where she has the opportunity to effect change that will inspire $21^{\text {st }}$-century learners. Email: sherine.douglas@mail. utoronto.ca
\end{abstract}

Chariandy, David. (2020). I've been meaning to tell you: A letter to my daughter. Bloomsbury.

From a father's perspective, writing a letter to your teenage daughter about the ills of the world can seem like a daunting task-one of mixed emotions without quite having the right words to say. In I've Been Meaning to Tell You: A Letter to My Daughter, David Chariandy does quite the opposite. I've Been Meaning to Tell You is a letter written by Chariandy in 2018, revealing to his 13-year-old daughter the current state of racial tensions in Canada carried from a history of colonial rule and power. In the letter, he describes a rich family history of South Asian and Trinidadian cultures, each one playing an important role in shaping his daughter's identity. Chariandy, born and raised in Canada, tells a story of disconnect and discrimination he suffered as a young Black boy growing up in Toronto. As a born Canadian often referred to as an "immigrant" or "visible minority," he speaks of the disassociation and lack of acceptance he experienced from his peers, his extended family members, and those at the top of power hierarchies. Chariandy refers to his former teachers, principals, politicians, his parents' employers, and those who benefit from white privilege as being at the top of such power hierarchies. Such power structures work within social systems to uphold white supremacist beliefs.

The book begins with Chariandy retelling the details of a visit to a local grocery store with his young daughter. As Chariandy approaches the public water fountain to refill his bottle, he is pushed out of the way by a white lady who intends to make him feel out of place. Irritated by his presence, she exclaims, "I was born here. I belong here." Describing this moment of bigotry witnessed at the young age of 3, Chariandy decides to write an intimate letter to his daughter to answer her question “Then what happened?" Chariandy's letter is relevant to current and future early childhood educators as they reflect on their own beliefs, experiences, and biases as they apply their personal praxis in the classroom setting.

Throughout I've Been Meaning to Tell You, Chariandy reflects on his own past encounters with racism and discrimination as others pass judgment based on his appearance. On his daughter's $13^{\text {th }}$ birthday, he becomes increasingly aware of the importance of sharing with her their family origins and the intersection of Canada's fictitious postcolonial harmony, to best prepare her for a life of race-conscious decisions she will have to make on her own. As he describes his own childhood journey, Chariandy attempts to unpack Canada's long legacy of tumultuous and unsettled relationships with marginalized groups-including the broken relationship between Canada and Indigenous peoples.

Chariandy's experiences of being a mixed-race citizen in a matrix of white-dominated power structures are not unique. As he described his childhood journey, I often wondered how many other nonwhite children have had similar experiences, and which children continue to experience marginalization within the education system. Do Chariandy's personal encounters with both overt and discreet acts of racism allow readers to question their own 
biases and thus reflect on their interactions with children? Further, can educators take away some wonderings of their own to question how they may unconsciously be replicating a biased system that remains dominated by white Eurocentric beliefs?

Throughout this book, from beginning to end, Chariandy often finds inspirational words that question the violent tragedies of the past, while raising the important influence these violent transgressions have on the country's current social, political, and economic systems. Chariandy's love for his daughter and his admiration for her individuality as she matured into a young lady encouraged him, as a father, to continue seeking beauty in the world to help cultivate her journey as biracial and as an empathetic citizen. Chariandy does not provide answers for his daughter; rather, he challenges her to think about what it means to be seen as a racialized Canadian. Although Chariandy does not do a profound analysis to expose the deep-seated issues surrounding systemic racism and institutional oppression originating from a colonial past, including the history of Indigenous peoples, in writing to his daughter, his personal reflection does provide the reader with a powerful example to reflect on their own intimacies with identity, allowing ample room to wonder about the love and beauty required to envision an improved future for marginalized people in Canada.

\section{About love}

Chariandy's love and admiration for his daughter are evident in each chapter of the book. It is his profound admiration and respect for her, paired with her own agency and confidence, that allows the reader to envision a brighter future; not only for his daughter, but for a society that is equally accepting of all races, genders, and cultures. In the letter to his daughter, Chariandy describes his own past experiences with racism and his struggle to feel loved. He often felt rejected and was singled out because of his differences. He suffered from extreme isolation in a neighbourhood where he saw others with his own skin colour, but they too suffered from overt acts of racism leading to low self-esteem and self-worth. Besides his own family members, he lacked any true connections to others. Now as a father, however, Chariandy admires the love for life that his daughter displays. It is with her inherently positive attitude that Chariandy's love translates to a feeling of confidence, knowing that his daughter is better prepared to fight the injustices of society. Regardless of his own unfortunate experiences with racism, he remains optimistic about a better future. In addition, it is through witnessing his daughter's self-love, along with her ability to see the good in others so easily, that he believes love will carry her from a history of hate. He writes, "To witness you, my daughter, so physically confident in your body, is to be awed and also to wonder at how much your childhood differs from mine. Certainly you possess a worldliness that was unthinkable to me at your age" (p. 6). Chariandy strongly believes that the strength his daughter exudes, and her will for life as she develops into a beautiful young lady, will provide her the compassion to overcome systemic barriers as she explores what it means to be biracial in Canada. Throughout the book, he presents many accounts of how he is deeply moved by the person she is and by the person she is becoming.

Moreover, Chariandy describes the admiration and respect he has for his parents as an unlikely couple whose survival of the journey made from Trinidad to Canada was made possible because of love. His father, a darkskinned South Asian man, and his mother, a lighter-skinned Trinidadian woman, overcame many hardships to provide a better future for their family. Their relationship was not only dismissed in the Black community, but at the time, it was also illegal for them to migrate to Canada. On his daughter's $13^{\text {th }}$ birthday, Chariandy refers to the unselfish love shared between his parents and their desire for a better life that ultimately led to his personal success as a writer and as a father. In that moment, he feels compelled to share his parent's love story to counteract the worry that appears on his daughter's face as she hears about the Muslim travel bans announced by the American government. But in the letter, Chariandy assures his daughter that the power of love will carry them through to a 
better tomorrow. He writes, "You were confused and worried.... I wanted suddenly to tell you the quieter story of your grandparents, a story of migration and struggle and also of love between races taught to distrust one another" (p. 12). In this moment, Chariandy expresses his gratitude for his parents' unconditional love and recognizes their love as the catalyst responsible for providing many opportunities for him and for his family. Chariandy's love for both his daughter and his parents radiates throughout the book; it is precisely this relentless love that allows the reader the opportunity to better understand the origins and effects of systemic acts of deliberate hate. As a result of accepting such truths, as Chariandy hopes for his daughter, readers can then educate others who are less informed about the harmful legacies of racism in Canada and how systems of oppression, specifically the education system, contribute to discrimination against people of colour. Revealing the past and educating about its current effects, the author suggests, will propel Canadians toward a promising future. However, while Chariandy certainly makes a convincing argument that love will prevail over hate, I wonder if this same belief can exist for nonfamilial relationships. A father and daughter can certainly have a relationship based on love, but what about educators and students? The Western school system often discourages any sort of open affection a teacher may want to show their students, such as hugs or a validating touch on the arm. While I personally believe that love must be embedded in everything related to student nurturing, I am not convinced that this is a shared belief among educators. Therefore, Chariandy's deep expression of gratitude for his parents that he then shares with his daughter as an opportunity to resist hatred may be challenging for educators to pass on to students in the classroom.

\section{About identity}

Ethnicity and race play an important role in one's identity. Although society often uses race to cripple people of colour with the purpose of segregation and division, Chariandy reimagines his daughter's race as a fitting opportunity for her to reclaim her future as her own. Throughout his childhood, Chariandy recalls how others identified him as an outsider, never possessing the racially accepted qualities to fit in among others. His hair was too curly, his skin was too dark, and his speech was not quite right. As a person of colour living in Canada, Chariandy first reflects on his own childhood experience with race and identity: "I was very noticeable, not only for how I looked but for how I spoke and acted, what I wore and possessed ... and so I grew up the embodiment of what some feared and refused to understand" (p. 63). In reflecting and in writing, Chariandy admits to his daughter that he never learned to accept himself. All along, he struggled with identity and self-love. Instead, he allowed others to fear him and tease him, which in turn made him feel unimportant and inferior, and he lacked true self-worth. Although Chariandy's experience with his own identity led to a lack of self-confidence and a period of isolation lasting from childhood through to adolescence, he remains hopeful for his daughter's future. He imagines how a transformative understanding of her own identity can have a meaningful effect on her future opportunities. In the letter to his daughter, Chariandy explores the Canadian myth of multiculturalism that falsely permeates the very fabric that makes up Canada. Multiculturalism has often been used as a pull factor for immigrants to build their families in Canada; however, as Chariandy writes about his parent's experience, he reveals that multiculturalism has been more successful at establishing a power of oppression that has managed to marginalize racialized peoples rather than provide opportunity. It is often believed that people of colour in Canada experience disadvantages and racism at disproportionate rates due to their own individual circumstances rather than the oppressive nature of the policies and procedures embedded in the practices of the Canadian government. Even with these barriers, Chariandy believes his daughter's biracial identity will give her the ability to choose how she wants to be identified by others in this world. He writes, "But the fact is that I've never actually named you one way or the other, never told you, authoritatively, what you are, racially speaking. I suppose that I have imagined, at times, that you, as such complexly mixed children, might have the opportunity to choose and declare your own identity" (p. 55). In addition, Chariandy emphasizes that a just future requires that all people of diverse 
backgrounds must be recognized as individuals, not by the colour of their skin but rather by how they choose to be identified. In retracing the historical misrecognition of racialized people as part of Canada's social identity, Chariandy calls attention to the importance of self-recognition and the importance of personal identity for a hopeful future. In reimagining the possibilities, Chariandy argues that there is no room for preoccupations about identifying one by their skin colour. He writes, "The future I yearn for is not one in which we will all be clothed in sameness, but one in which we will finally learn to both read and respectfully discuss our differences" (p. 108). Chariandy encourages the reader to reflect, not only about the future, about systemic racism and the continued poor treatment of people of colour in Canada, but about how personal identity affects how we interact with others in the world-either to the betterment or to the detriment of ourselves and others. Chariandy's letter carries the reader to a space of optimism. By imagining a future where society can "respectfully discuss differences," he underlines the importance of first understanding one's own past as the necessary tool to envision a genuinely different future-where identities are chosen and not assigned. By encouraging his daughter to choose her own identity as a means of mobilization, Chariandy invites the reader to do the same. Shaping one's identity becomes fundamental in reimagining a future of possibilities. Educators can certainly take on this challenge as presented by Chariandy. ECEs have the unique opportunity to engage with students as they encounter the education system for the first time. In these settings, educators can begin to break down the barriers of identity and the molds that students are often asked to fit. The responsibility of choosing one's own identity, as Chariandy suggests, certainly lies with each individual student. However, the opportunity to suggest such dismantling of a prescriptive system is the responsibility of the classroom teacher.

\section{About beauty}

Chariandy's ability to see the beauty in an unjust world gives the reader hope for imagining a better future. In his letter to his daughter, Chariandy describes beauty in places where it is often overlooked. His consistent acknowledgment of beauty allows the ugliness of racism to fade, losing its credibility. When reminiscing about his college days, for example, he finds beauty when his Black friend recounts a very narrow escape from a gunshot as a result of police profiling. Chariandy writes,

But my roommate with the shy-gentle eyes was laughing all the same. What was so funny? 'We made it here,' he explained. We stared at him before realizing it was true. We found allies. We'd found each other. We were lucky.... My roommate stood there with a silly smile on his face. Soon we were all wearing it. Before the birth of both you and your brother, dearest daughter, these were the most beautiful smiles l'd ever seen. (pp. 83-84)

Chariandy writes about the importance of noticing beauty in the world as a way to escape tragedy. Choosing to focus on beauty instead of tribulation, Chariandy offers to his daughter another possibility-a possibility for Canadians to embrace a future that includes equality for all races. He writes,

You did not create the inequalities and injustices of this world, daughter. You are neither solely nor uniquely responsible to fix them. If there is anything to learn from the story of our ancestry, it is that you should respect and protect yourself; that you should demand not only justice but joy; that you should see, truly see, the vulnerability and the creativity and the enduring beauty of others. (p. 51 , emphasis in original)

Chariandy's reference to beauty and choosing joy as a way to prosperity parallels the sentiments Christina Sharpe (2019) illustrates her mother also expressed as she brought beauty into her childhood home. In her essay "Beauty is a Method" Sharpe recalls, 
She brought beauty into that house in every way that she could; she worked at joy, and she made livable moments, spaces, and places in the midst of all that was unlivable there, in the town we lived; in the schools we attended; in the violence we saw and felt.

Actively choosing to see beauty and " $d o$ " beauty as an active process to negate the things we cannot control is equally emphasized by Chariandy in writing to his daughter. To imagine a better future, Chariandy maintains that honouring one's unique past and seeking the beauty in all nearby things will allow individuals to demand change to the oppressive system in which we currently live.

\section{What Chariandy misses in his letter}

Although Chariandy does raise concerns about Canada's complex relationship with Indigenous peoples, he does not address the history in sufficient detail that warrants any change to current beliefs or practices. Further, he does not describe to his daughter the ways in which this relationship particularly impacts the lives of Blacks and African peoples who were forcibly removed from their original lands and relocated to Canada as slaves for nearly two hundred years. At one point in his letter, he describes his own understanding (or lack thereof) of Indigenous peoples represented as the past and the "unease" he felt celebrating the winter Olympics in Vancouver. Although Chariandy does bring the truth to light for his daughter, he does little to explain the importance of learning from this violent history upon which Canada was founded. He misses an opportunity to mark the historical significance and the obligation of citizens to not only acknowledge the sorrow of Indigenous peoples, but to impress upon his daughter the need to take action that does not contribute any further to the mistreatment of Indigenous peoples and their culture. Here, Chariandy misses a profound teachable moment for his daughter.

\section{Moving forward}

Chariandy's letter to his daughter is an intimate recounting of Canada's systemic racist history, including slavery and indenture. However, by combining love, identity, and beauty in his letter, he reveals a dark past only to demonstrate the possibility of a brighter future. Chariandy recognizes the significance in telling his daughter, as she is entering her first year of junior high school, the truth about her racial identity and how others may treat her because of it. Self-identity and honouring the past are both essential in moving forward-these are critical lessons to be taught at school and at home. A Letter to My Daughter can be used by early childhood educators to encourage young children to engage with their cultural identity. Chariandy's work can encourage educators to deepen their own knowledge of self-identity and bring awareness to the biases they bring to the classroom. Since early childhood programs are often the first point of contact for many children and their families, making the connection between home and school should not be overlooked. By using narrative pieces, teachers could explore the concepts of identity and the importance of understanding one's past to inform their future. This short, easy-to-read book can be read aloud in the classroom to engage students in the inquisitive space of alternative discourses. Early childhood educators can introduce the concepts of love, beauty, and identity that Chariandy explores to illustrate these themes through interactive play, art, and dance with young children. For an extended study, educators can apply the concepts from A Letter to My Daughter to engage in a deep reflection of both their personal and professional identities. Chariandy's letter raises the necessity of asking critical questions regarding the possibilities of an anti-Black-racist future and the importance of honouring different identities-racial identities and beyond. Chariandy's work contributes to the balance of acknowledging a painful truth and the timely message of necessary change as he leaves his daughter (and the reader) with a message of inspiration:

Now you speak your own truths and you will continue to find the scripts that honour your body and experience and history, each of these scripts a gift, and none of them fully adequate to the holy force 
of you.... You are not what they see and say you are. You are more. (pp. 84, 120)

Chariandy's letter to his daughter is an intimate account of his own ancestral past, and it demonstrates the politics of race and the compassion required to combat it. This book is a must read for all educators and for those who believe in brighter possibilities for a better future-a future that embraces differences rather than discriminates against them. 


\section{References}

Sharpe, C. (2019, December). Beauty is a method. E-flux Journal, 105. https://www.e-flux.com/journal/105/303916/beauty-is-a-method/ 